\title{
Simplified micrometric surface characterization of different implant surfaces available on the Brazilian market
}

Luiz Carlos do Carmo Filho', Ana Paula Pinto Martins², Amália Machado Bielemann ${ }^{3}$, Anna Paula da Rosa Possebon ${ }^{3}$, Fernanda Faot ${ }^{4}$

${ }^{1} \mathrm{MSc}, \mathrm{PhD}$, Department of Prosthodontics and Periodontology, Piracicaba Dental School, State University of Campinas, Piracicaba, SP, Brazil

${ }^{2} \mathrm{MSc}$, Graduate Program in Dentistry, School of Dentistry, Federal University of Pelotas, RS, Brazi

${ }^{3} \mathrm{PhD}$, Graduate Program in Dentistry, School of Dentistry, Federal University of Pelotas, RS, Brazil

${ }^{4} \mathrm{PhD}$, Professor, Department of Restorative Dentistry, School of Dentistry, Federal University of Pelotas, RS, Brazil.
Corresponding author: Prof. Dra. F. Fao Department of Restorative Dentistry, School of Dentistry, Federal University of Pelotas, Gonçalves Chaves St., 457, Center Pelotas, RS, Brazil, 96015560 Phone/Fax: +55 5332256741 E-mail: fernanda.faot@gmail.com

Received: March 07, 2018 Accepted: June 01, 2018
Aim: This study characterized the implant surfaces available on the Brazilian market in terms of topography, chemical composition, and roughness. Methods: The following brands were selected according to their surfaces: Kopp (Ko), Signo Vinces (Sv), Neodent (Ne), Osseotite (Os), Nanotite (Nt), SIN (Si), Titanium Fix (Tf), conventional Straumann (Str), SLActive (SLA). The morphological analysis and the alloy impurities and implant surface contaminants were analyzed by SEM-EDS. Surface roughness parameters and 3-D reconstructions were obtained by laser microscopy (20x). Two distinct areas were evaluated: i) the cervical portion (no surface treatment), and ii) the middle third (treated surface). Results: The characterization of the implant surfaces by SEM showed morphological differences between the thread geometries and surface morphology at 800x and 2000x magnification. The EDS elemental analysis showed a predominance of titanium (Ti) for all implants. The SLA surface showed only peaks of Ti while other implants brands showed traces of impurities and contaminants including Al, C, PR, F, Mg, $\mathrm{Na}, \mathrm{Ni}, \mathrm{O}, \mathrm{P}$, and $\mathrm{SR}$. The implant surface roughness in the cervical portion did not exceed Ra 0.5-1.0 $\mu \mathrm{m}$, constituting a minimally rough surface and obtaining acceptable standards for this region. Only Nt, Str, and SLA presented Ra above $2 \mu \mathrm{m}$ in the middle third area showing a rough surface favorable for osseointegration. Conclusion: This study concluded that there is no established standard for morphology, chemical composition and implant surface roughness that allows a safe comparison between the available dental implant surfaces. National implant brands generally contain more impurities and surface contaminants than their international counterparts and were consequently more sensitive to the surface treatment techniques.

Keywords: Dental Implants, Surface Properties, Energy Dispersive X-ray Spectroscopy. 


\section{Introduction}

The discovery of osseointegration enabled treatment of totally and partially edentulous patients with dental implants ${ }^{1}$. In a previous study, Branemark $(1977)^{2}$ stated that direct contact between vital bone tissue and implant is totally predictable, safe and long-lasting, and thus constitutes an important parameter for clinical success ${ }^{3}$. Insights in healing and repair processes contributed to the modification of the implant surface treatments and designs. Surface roughness, macro, and microgeometry influence the cell proliferation and differentiation, extracellular matrix synthesis, local cell production factors, and even cell shape ${ }^{4}$. Therefore, the treatment used on the implant surface directly affects the implant's survival rate and has been the focus of intense study ${ }^{3}$

When the osseointegration is triggered, the osteoblast adhesion to the implant surface is required for the cell to receive signals that induce osteoblastic proliferation ${ }^{5}$. Adopting rough implant surfaces can facilitate the retention of the osteogenic cells and can accelerate their migration through osseoconduction ${ }^{6}$. Consequently, a high quality bone-implant interface guarantees faster and stronger bone formation that in turn promotes greater stability during the repair process ${ }^{7-9}$. The primary stability is a predictor for successful osseointegration ${ }^{10}$. Geometry can also be factor, as spherical materials induce less fibrous encapsulation than cylindrical or sharp angles ${ }^{11}$. The quality of the bone-implant interface also depends on the implant's ability to support loading, mainly because overload biomechanics increase the bone density in the long-term and overloading might influence peri-implant tissue breakdown when plaque accumulation is present ${ }^{12}$. The systematic review of in vivo data evidenced a differential peri-implant bone tissue response to overloading, depending on the mucosal health: supra-occlusal contacts in a non-inflamed peri-implant environment did not negatively affect osseointegration and are even anabolic ${ }^{12}$. A combination of all the aforementioned factors can influence the clinical success of dental implants.

In recent years, some studies 5,7,13,14 have measured the dental implants surfaces at macro, micro, and nanometric scales, to investigate how the different surfaces influence the bone repair process. Although there are studies available that analyze the influence of surface roughness, little is known about the physico-chemical properties of the implant surfaces. This information is generally restricted to the implant package specifications and informational catalogs provided by the manufacturers ${ }^{15}$. Furthermore, the gold standard test to characterize the physical properties of implant surface treatments is interferometry, an expensive and time-consuming technique. This study aims to characterize the surface roughness of different commercial implant brands available in Brazil using scanning electron microscopy images in conjunction with laser microscopy, a simplified interferometrical technique that has been sucessfully applied in the material engineering sciences ${ }^{16}$.

\section{Materials and Methods}

Seven commercial brands available on the Brazilian market with nine different surfaces were randomly selected for this study: Kopp (Ko, HEX Ø3.75 x 11.0mm), Neodent (Ne, Titamax TI Cortical Ø3.5 x 11.0mm), Signo Vinces (Sv, Duo Ø3.8 x 10mm), 
SIN (Si, Tryon $\varnothing 3.75 \times 10 \mathrm{~mm}$ ), Straumann (Str, SLA and SLA, SLActive with dimensions $\varnothing 4.1 \times 8.0 \mathrm{~mm}$ ), Titanium Fix (Tf, self-tapping Implant $\varnothing 4.0 \times 13.0 \mathrm{~mm}$ ), Biomet 3i ( $\mathrm{Nt}$, Nanotite ${ }^{\mathrm{TM}} \varnothing 4.0 \times 8.5$ and, Os, Osseotite $\left.{ }^{\circ} \varnothing 3.75 \times 8.5 \mathrm{~mm}\right)$. The description of the surface treatment of each implant is listed in Table 1 . Surface analysis was performed using a laser microscope (Lext OLS 4000 OLYMPUS), with 20x objective lenses (MPLAPON), 1x zoom, with a magnification of 432x - 3.456x, and field of view of $640-80 \mu \mathrm{m}$. The in-house software provided with the equipment allowed to describe several parameters of roughness $(R)$ in micrometers in a single surface reading.

Table 1. Description of the type of surface treatment for the studied commercial brands.

\begin{tabular}{|c|c|}
\hline Brand & Surface teatment description \\
\hline KOPP & Sandblasting and double acid subtraction ${ }^{25}$ \\
\hline SIGNO VINCES & Sandblasting with aluminum oxide particles and chemical treatment by double acid etching ${ }^{26}$ \\
\hline NEODENT & Sandblasting and acid subtraction (Neoporos Surface) ${ }^{27,28}$ \\
\hline SIN & Double acid-etching ${ }^{29}$ \\
\hline TITANIUM FIX & Sandblasting and acid-etching ${ }^{30}$ \\
\hline OSSEOTITE® & Double acid-etching ${ }^{31,32}$ \\
\hline NANOTITE® & Double acid-etching with CaP crystals deposition $29,31,32$ \\
\hline STRAUMANN SLA & Sandblasting with large grits of 0.25 to $0.50 \mathrm{~mm}$ and acid-etching with $\mathrm{HCl} / \mathrm{H} 2 \mathrm{SO}^{23}$ \\
\hline $\begin{array}{l}\text { STRAUMANN } \\
\text { SLACTIVE }\end{array}$ & Sandblasting, large-griting, acid-etching and rinsed under nitrogen submerge in $\mathrm{NaCl}$ solution ${ }^{33}$ \\
\hline
\end{tabular}

In this study, we used the following parameters: Rp (maximum profile peak height / peak height of the highest roughness); Ry (maximum distance between peak and valley); Rz ( maximum height of profile / represents the arithmetic mean of the 5 values); Rt (total height of profile); Ra (arithmetic mean deviation of profile / represents the average profile roughness - amplitude parameter defined as integral and absolute value of the height of peaks and valleys, along the evaluated profile) ${ }^{17}$. In addition, the surfaces studied were reconstructed in a 3-D format using the OLS 40002.1 Software to process and obtain 20x magnified images (Figure 1).
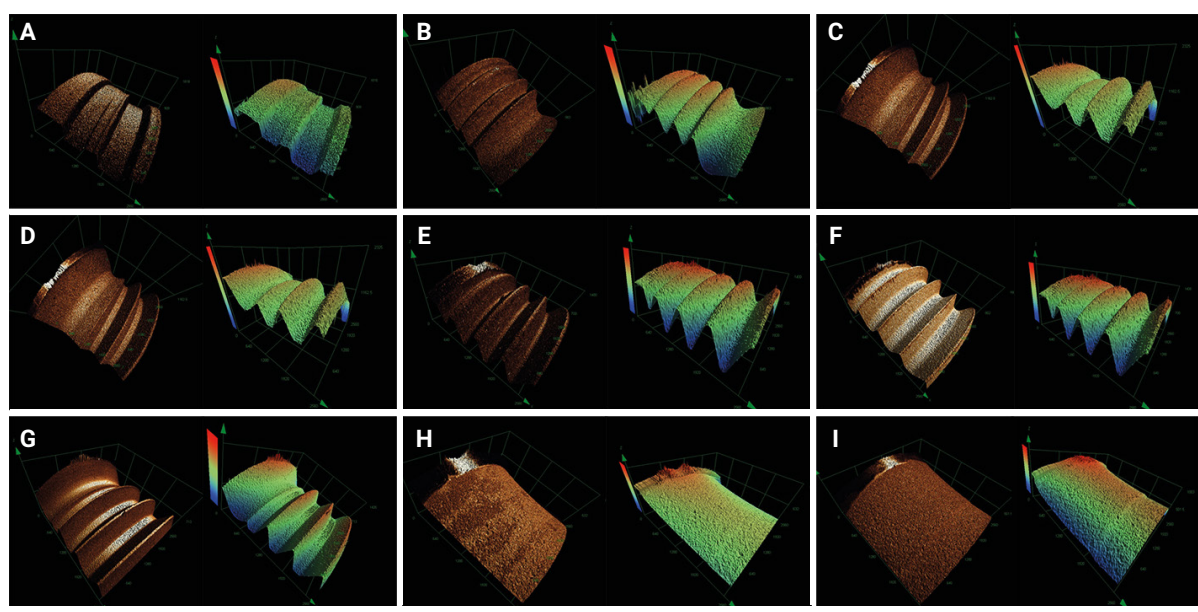

Figure 1. 3D reconstructions showing the surface morphology of the implants: A: Kopp; B: Signo Vinces; C: Neodent D: SIN; E: Titanium Fix; F: Biomet 3i Osseotite; G: Biomet 3i Nanotite; H: Straumann SLA; I: Straumann SLActive. 
The implants surface morphologies and the elemental analysis were performed using a scanning electron microscopy (SEM) and energy dispersive X-ray spectrometry (EDS) (SSX-550; Shimadzu, Tokyo, Japan) to identify the elements present on the implant surface. Two regions of the implant were selected to perform the analyses: i) the cervical region (without surface treatment), and ii) the medium third (treated surface).

\section{Results}

The 3-D reconstructions showing the surface morphology of the 7 implant types are shown in Figure 1, while Figure 2 presents the SEM images showing the implant surface morphologies. Table 2 lists the results of the implant surface roughness analysis for the different commercial brands in their cervical and middle regions. The cervical portion of all implants can be considered minimally rough, while the middle region may range from minimally rough to rough $(\mathrm{Ra}>2.0 \mu \mathrm{m})$.

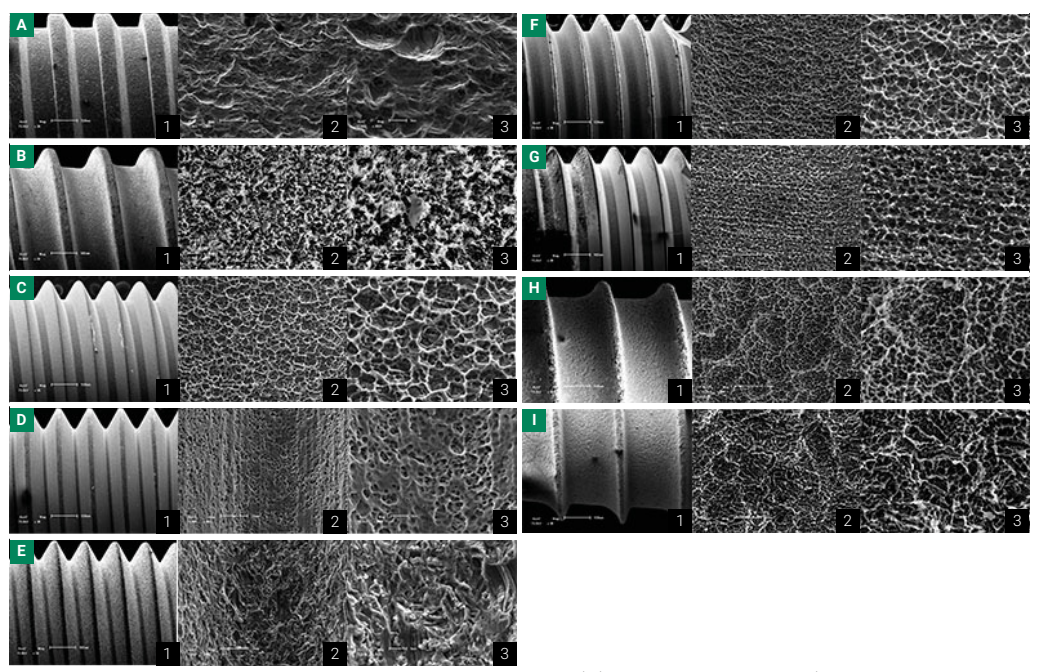

Figure 2. Scanning electron microscopy images showing (1) thread geometry (original magnification 30x $500 \mu \mathrm{m}$ ), (2) surface morphology (magnification $800 \times 20 \mu \mathrm{m}$ ) and (3) surface morphology (magnification

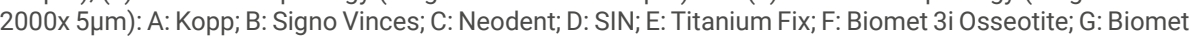
3i Nanotite; H: Straumann SLA; I: Straumann SLActive.

Table 2. Roughness parameters of the studied implant surfaces in the cervical and middle third regions of the different commercial brands at the micrometric level $(\mu \mathrm{m})$.

\begin{tabular}{lcccccccccc}
\hline \multirow{2}{*}{ IMPLANT } & \multicolumn{2}{c}{ Rp } & \multicolumn{2}{c}{ Ry } & \multicolumn{2}{c}{ Rz } & \multicolumn{2}{c}{ Rt } & \multicolumn{2}{c}{ Ra } \\
\cline { 2 - 12 } & Cervical & Middle & Cervical & Middle & Cervical & Middle & Cervical & Middle & Cervical & Middle \\
\hline KOPP & 2.696 & 5.256 & 1.037 & 4.228 & 3.733 & 9.485 & 7.659 & 14.651 & 0.455 & 1.557 \\
\hline SIGNO VINCES & 2.26 & 5.494 & 0.876 & 8.419 & 3.136 & 13.913 & 9.187 & 32.53 & 0.492 & 1.814 \\
\hline NEODENT & 1.738 & 4.638 & 0.487 & 2.973 & 2.225 & 7.611 & 8.256 & 9.681 & 0.291 & 1.034 \\
\hline SIN & 2.419 & 2.862 & 0.71 & 2.848 & 3.129 & 5.71 & 8.647 & 7.779 & 0.323 & 0.7 \\
\hline TITANIUM FIX & 1.553 & 10.332 & 0.921 & 4.156 & 2.474 & 14.488 & 5.622 & 86.219 & 0.337 & 1.404 \\
\hline OSSEOTITE & 5.883 & 5.037 & 0.686 & 4.474 & 6.568 & 9.511 & 11.444 & 27.264 & 0.706 & 1.086 \\
\hline NANOTITE & 1.68 & 20.548 & 1.796 & 9.461 & 3.477 & 30.01 & 9.704 & 44.742 & 0.469 & 3.436 \\
\hline STRAUMANN SLA & 0.699 & 9.95 & 0.873 & 8.279 & 1.572 & 18.229 & 3.96 & 24.917 & 0.243 & 3.091 \\
\hline STRAUMANN & 0.831 & 11.304 & 1.723 & 8.691 & 2.554 & 19.955 & 10.821 & 46.28 & 0.305 & 2.997 \\
SLACTIVE & & & & & & & & & & \\
\hline
\end{tabular}


The EDS elemental analysis shows that only the SLA implant surface is composed of pure titanium; all other implant surfaces contained significant amounts of different elements, as described in Table 3 and Figure 3.

Table 3. Elemental composition of the studed implant surfaces (in weight \%) measured with energy dispersive spectrometry (EDS).

\begin{tabular}{lccccccccccc}
\hline IMPLANT & $\mathrm{Ti}$ & $\mathrm{Al}$ & $\mathbf{M g}$ & $\mathbf{C}$ & $\mathbf{F}$ & $\mathbf{N a}$ & $\mathrm{SR}$ & $\mathrm{PR}$ & $\mathbf{N i}$ & $\mathbf{0}$ & $\mathbf{P}$ \\
\hline KOPP & 95.289 & 0.580 & 0.605 & 3.526 & $\mathrm{x}$ & $\mathrm{x}$ & $\mathrm{x}$ & $\mathrm{x}$ & $\mathrm{x}$ & $\mathrm{x}$ & $\mathrm{x}$ \\
\hline SIGNO VINCES & 98.559 & 1.441 & $\mathrm{x}$ & & $\mathrm{x}$ & $\mathrm{x}$ & $\mathrm{x}$ & $\mathrm{x}$ & $\mathrm{x}$ & $\mathrm{x}$ & $\mathrm{x}$ \\
\hline NEODENT & 81.807 & $\mathrm{x}$ & $\mathrm{x}$ & & 1.463 & 0.637 & 1.011 & 15.082 & $\mathrm{x}$ & $\mathrm{x}$ & $\mathrm{x}$ \\
\hline SIN & 73.092 & 0.582 & $\mathrm{x}$ & 5.571 & $\mathrm{x}$ & $\mathrm{x}$ & & 20.755 & $\mathrm{x}$ & $\mathrm{x}$ & $\mathrm{x}$ \\
\hline TITANIUM FIX & 18.849 & 5.880 & 0.231 & 2.252 & 1.317 & $\mathrm{x}$ & $\mathrm{x}$ & $\mathrm{x}$ & 29.487 & 10.856 & $\mathrm{x}$ \\
\hline OSSEOTITE & 91.967 & $\mathrm{x}$ & $\mathrm{x}$ & 8.033 & $\mathrm{x}$ & $\mathrm{x}$ & $\mathrm{x}$ & $\mathrm{x}$ & $\mathrm{x}$ & $\mathrm{x}$ & $\mathrm{x}$ \\
\hline NANOTITE & 69.997 & 6.688 & $\mathrm{x}$ & 6.643 & $\mathrm{x}$ & $\mathrm{x}$ & $\mathrm{x}$ & 16.199 & $\mathrm{x}$ & $\mathrm{x}$ & 0.473 \\
\hline $\begin{array}{l}\text { STRAUMANN } \\
\text { SLA }\end{array}$ & 99.905 & 0.095 & $\mathrm{x}$ & & $\mathrm{x}$ & $\mathrm{x}$ & $\mathrm{x}$ & $\mathrm{x}$ & $\mathrm{x}$ & $\mathrm{x}$ & $\mathrm{x}$ \\
\hline $\begin{array}{l}\text { STRAUMANN } \\
\text { SLACTIVE }\end{array}$ & 100.000 & $\mathrm{x}$ & $\mathrm{x}$ & $\mathrm{x}$ & $\mathrm{x}$ & $\mathrm{x}$ & $\mathrm{x}$ & $\mathrm{x}$ & $\mathrm{x}$ & $\mathrm{x}$ & $\mathrm{x}$ \\
\hline
\end{tabular}

\section{Discussion}

The characteristics of the bone-implant interface and the methods to improve this relationship such as implant surface modifications have been intensely studied ${ }^{18}$. The average surface roughness of the implants, represented by $\mathrm{Ra}$, is a widely investigated parameter by interferometry. Our study was the first that described a simplified laser methodology for implants surface roughness characterization. According to Albrektsson and Wennerberg ${ }^{13}$ (2004), the surfaces can be classified according to the Ra value as: i) minimally coarse: Ra $0.5-1.0 \mu \mathrm{m}$, present in machine turned implants; ii) moderately rough: Ra $1.0-2.0 \mu \mathrm{m}$, found in implants with acid-conditioned, blasting or anodized surfaces; and iii) rough: $\mathrm{Ra}>2.0 \mu \mathrm{m}$, as found in implants treated with plasma spray. However, the precise characterization of the surface morphologies is still a topic of discussion. Most implant surface studies ignore the chemical aspects 18; chemical characterization of commercially available products is extremely scarce in the literature ${ }^{19,20}$. In contrast, surface morphology and micrometer-scale topography are commonly used, but the optimal method to quantify microstructures remains a source of debate ${ }^{21}$.

The implant surface characteristics can influence the initial biofilm formation, because the adhesion of the microorganisms is directly proportional to the surface roughness. Therefore, the cervical portion of the implants ideally should have a smoother surface, because this region of the implant is most exposed to the buccal environment. A smoother surface reduces bacterial adhesion and consequently reduces the incidence of peri-implant pathologies that can lead to implant failure ${ }^{22}$. The Ra values in the cervical portion of (Table 2) did not exceed $1.0 \mu \mathrm{m}$ in the national implant brands, characterizing a minimally rough surface ${ }^{13}$. The latter implies that all brands presented acceptable micrometric patterns, capable of safely avoid biofilm accumulation in the peri-implant region. However, when other roughness parameters are included, a great disparity of values is observed, and all implants surfaces evaluated. The Nt surface 

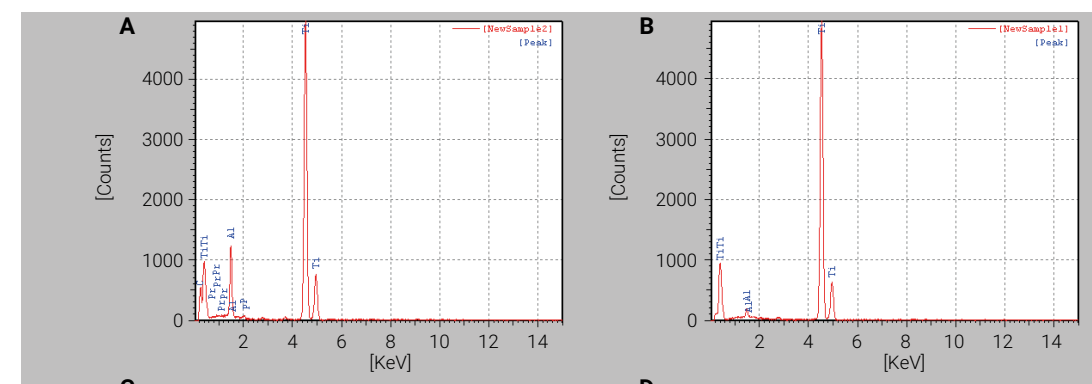

C

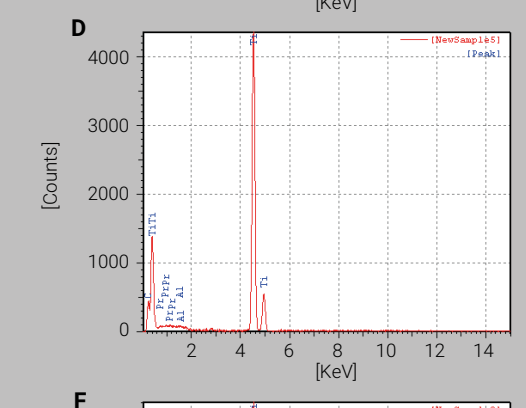

$\frac{\bar{m}}{5}$
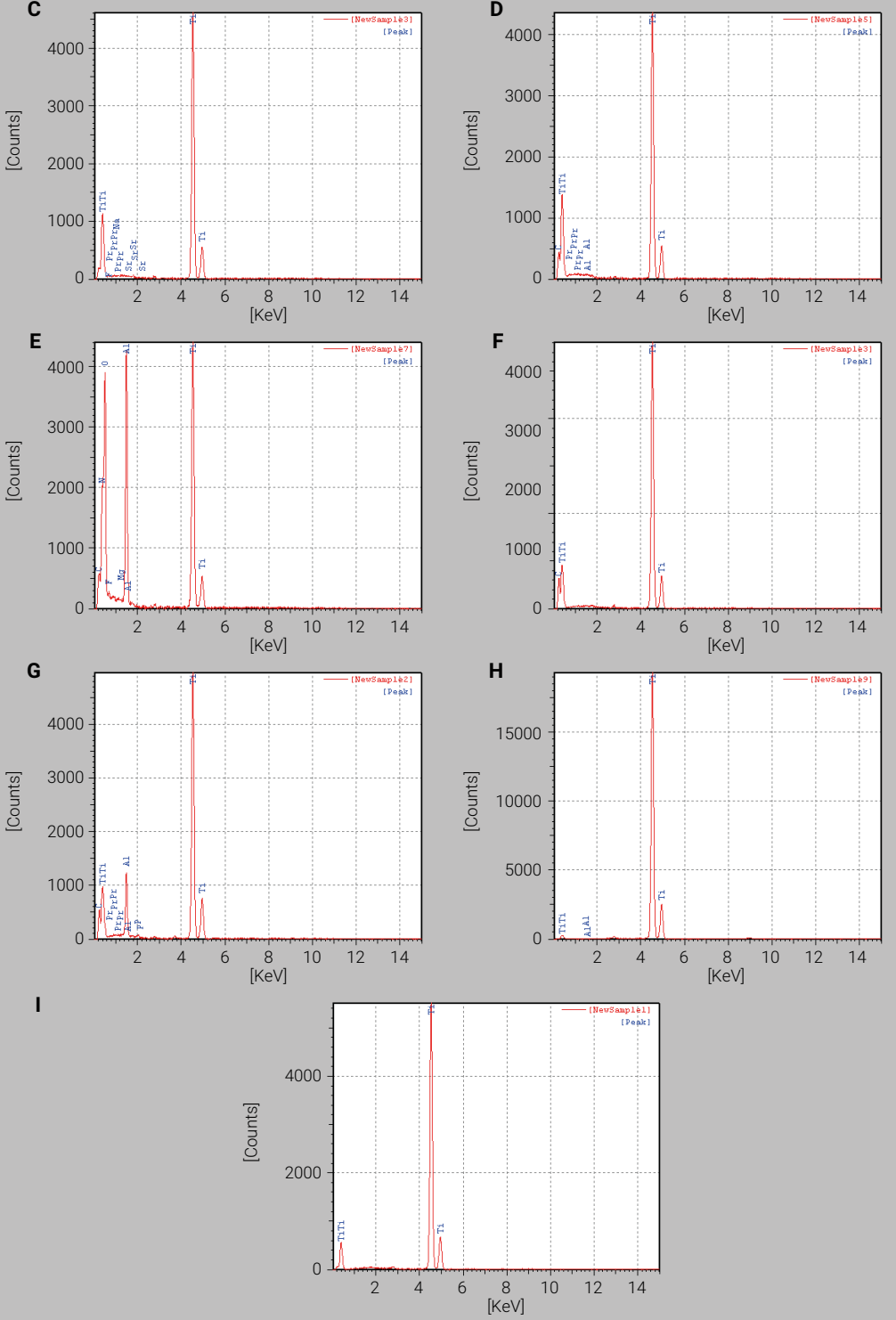

Figure 3. Spectra obtained by EDS analysis of the middle third of the surface topography of the evaluated implants: A: Kopp; B: Signo Vinces; C: Neodent; D: SIN; E: Titanium Fix; F: Biomet 3i Osseotite; G: Biomet 3i Nanotite; H: Straumann SLA; I: Straumann SLActive 
generally presented the highest roughness values in the middle portion of the implant (4 of 5 parameters evaluated) while the SLA surface presented the lowest roughness parameters in the cervical part, in accordance with the available literature ${ }^{13,23}$. In our study, Str and SLA surfaces presented similar roughness as described in previous studies, yet SLA surfaces presented greater bone-to-implant contact areas during the early stages of bone healing ( 2 and 4 weeks) $)^{7,23}$.

The surfaces Nt, Str and SLA presented mean Ra values above $2 \mu \mathrm{m}$ in the middle third region. While high roughness promotes the retention of the osteogenic cells on the surface ${ }^{5,6}$, Ra values exceeding $2 \mu \mathrm{m}$ can lead to an impaired and unenhanced bone response ${ }^{5}$. The SIN implant surface was characterized as minimally rough (Ra $0.7 \mu \mathrm{m})$ and presented the lowest values of roughness in the middle region compared to other commercial brands, mainly in terms of the Ry and Rz parameters. The Nt surface presented the highest Rp value (maximum height of the highest peak of the roughness) and the $\mathrm{Tf}$ surface presented a high value of Rt (the total height of the profile). These rough spots probably represent the locations where the first osteoblastic cells will attach.

The EDS analysis showed that only the implant with SLA surface is free of contaminations and impurities (Figure 1 and Table 3). This implant is immersed in water when sold, thus minimizing previous contamination. All other implants can be considered contaminated, and these impurities can determine the biological performance of the implant, and may be responsible for future osseointegration failures ${ }^{24}$. These results corroborate the study of Dohan Ehrenfest et al. ${ }^{18}$ (2011) that detected inorganic contaminations, such as $\mathrm{Na}, \mathrm{P}, \mathrm{Ca}, \mathrm{F}$, and $\mathrm{S}$ in the evaluated implants. Therefore, even if dental implants are carefully manufactured, the results are not homogeneous; similar implant surface treatments do not necessarily yield identical results ${ }^{7}$. In addition, when the macrometric topography of an implant surface changes, its micrometric and chemical characteristics can also undergo changes, sometimes accidentally. Therefore, it is essential that each implant design has a suitable surface treatment to achieve an acceptable roughness ${ }^{15}$

A large number of experimental investigations have clearly demonstrated that the bone response is influenced by the implant surface. Our study adopted a simplified methodology and showed that there is no pre-established roughness pattern that allows a safe comparison of different commercial brands available in Brazil. Therefore, it is necessary to perform more laboratory and clinical studies to investigate the ideal roughness characteristics that accelerate and maintain osseointegration. A limitation of this study is that only a qualitative analysis with one implant per brand was performed, precluding a statistical analysis.

In conclusion, dental implants are currently marketed without clearly defined surface characteristics. Our study was the first that described a simplified laser methodology for implants surface roughness characterization. The results indicate that there is no pre-established roughness pattern that easily allows a safe comparison of the available different dental implants brands. The SEM-EDS data indicate that national implant brands generally present higher amounts of impurities and elemental contamination than their international counterparts. 


\section{References}

1. Aksoy U, Eratalay K, Tozum TF. The possible association among bone density values, resonance frequency measurements, tactile sense, and histomorphometric evaluations of dental implant osteotomy sites: a preliminary study. Implant Dent 2009;18(4):316-325.

2. Brånemark PI. Osseointegrated implants in the treatment of the edentulous jaw. Experience from 10 year period. Scand J Plast Reconst Surg 1977;16(1):1-32.

3. Shalabi MM, Wolke JG, Jansen JA. The effects of implant surface roughness and surgical technique on implant fixation in an in vitro model. Clin Oral Implants Res 2006;17(2):172-178.

4. Anselme K, Bigerelle M. Topography effects of pure titanium substrates on human osteoblast longterm adhesion. Acta Biomater 2005;1(2):211-222.

5. Elias CN, Meirelles L. Improving osseointegration of dental implants. Expert Review of Medical Devices 2010;7(2):241-256.

6. Braceras I, De Maeztu MA, Alava JI, Gay-Escoda C. In vivo low-density bone apposition on different implant surface materials. Int J Oral Maxillofac Surg 2009;38(3):274-278.

7. Wennerberg A, Albrektsson T. On implant surfaces: a review of current knowledge and opinions. Int $J$ Oral Maxillofac Implant 2010;25(1):63-74.

8. Albrektsson T, Brånemark PI, Hansson HA, Lindström J. Osseointegrated titanium implants. Requirements for ensuring a long-lasting, direct bone-to-implant anchorage in man. Acta Orthop Scand 1981;52(2):155-70.

9. Fröjd V, Wennerberg A, Franke Stenport V. Importance of $\mathrm{Ca}(2+)$ modifications for osseointegration of smooth and moderately rough anodized titanium implants - a removal torque and histological evaluation in rabbit. Clin Implant Dent Relat Res 2012;14(5):737-45.

10. Javed F, Ahmed HB, Crespi R, Romanos GE. Role of primary stability for successful osseointegration of dental implants: Factors of influence and evaluation. Interv Med Appl Sci 2013;5(4):162-167.

11. Ogle ME, Segar CE, Sridhar S, Botchwey EA. Monocytes and macrophages in tissue repair: Implications for immunoregenerative biomaterial design. Exp Biol Med 2016;241(10):1084-1097.

12. Naert I, Duyck J, Vandamme K. Occlusal overload and bone/implant loss. Clin Oral Implants Res 2012;23(SUPPL.6):95-107.

13. Albrektsson T, Wennerberg A. Oral implant surfaces: Part 1--review focusing on topographic and chemical properties of different surfaces and in vivo responses to them. Int J Prosthodont 2004; 17(5):536-543.

14. Wennerberg A, Albrektsson T. Effects of titanium surface topography on bone integration: A systematic review. Clinical Oral Implants Research 2009;20(SUPPL. 4):172-184.

15. Rosa MB, Albrektsson T, Francischone CE, Filho HOS, Wennerberg A. Micrometric characterization of the implant surfaces from the five largest companies in Brazilian market. Part I: Neodent Implants. Dent Press Implantol 2012;6(1):76-87.

16. Rosa MB, Albrektsson T, Francischone CE, Filho HOS, Wennerberg A. Micrometric characterization of the implant surfaces from the five largest companies in Brazil, the second largest worldwide implant market. Int J Oral Maxillofac Implants 2013;28(2):358-65.

17. Kaplonek W, Nadolny K. Advanced 3D laser microscopy for measurements and analysis of vitrified bonded abrasive tools. J Eng Sci Technol 2012;7(6):661-678.

18. Dohan Ehrenfest DM, Vazquez L, Park Y-J, Sammartino G, Bernard J-P. Identification Card and Codification of the Chemical and Morphological Characteristics of 14 Dental Implant Surfaces. J Oral Implantol 2011;37(5):525-542. 
19. Morra M, Cassinelli C, Bruzzone G, Carpi A, Di Santi G, Giardino R, Fini M. Surface chemistry effects of topographic modification of titanium dental implant surfaces: 1. Surface analysis. Int J Oral Maxillofac Implants 2003;18(1):40-5.

20. Kang B-S, Sul Y-T, Oh S-J, Lee H-J, Albrektsson T. XPS, AES and SEM analysis of recent dental implants. Acta Biomater 2009;5(6):2222-9.

21. Wennerberg A, Albrektsson T. Suggested guidelines for the topographic evaluation of implant surfaces. Int J Oral Maxillofac Implants 2000;15(3):331-44.

22. Bertolini M, Portella MB, Telles DM, Lourenco EJ V. The influence of implant surface properties with soft tissue response and biofilm formation. Implant News 2011;8(3):307-312.

23. Buser D, Broggini N, Wieland M, Schenk RKK, Denzer AJJ, Cochran DLL, Hoffmann B, Lussi A, Steinemann SGG, 1Department. Enhanced Bone Apposition to a Chemically Modified SLA Titanium Surface. Implant News 2011;8(3):307-312.

24. Oshida Y, Tuna EB, Aktören O, Gençay K. Dental Implant Systems. Int J Mol Sci 2010;11(12):1580-1678.

25. Gerzson A da S, Peres CA, Rosa MB, Fetter EP, Marchioni LA. Surfaces in Implantology Characteristics of the main Brazilian implants. Dent Press Implantol 2013;7(4):46-51.

26. Teixeira HS, Marin C, Witek L, Freitas A, Silva NRF, Lilin T, Tovar N, Janal MN, Coelho PG. Assessment of a chair-side argon-based non-thermal plasma treatment on the surface characteristics and integration of dental implants with textured surfaces. J Mech Behav Biomed Mater 2012;945-49.

27. Neodent. Catálogo Neodent. Neodent 2017;11-212. http://www.neodent.com.br/catalogo/ (2017, accessed January 4, 2018).

28. Sartoretto SC, Alves ATNN, Resende RFB, Calasans-Maia J, Granjeiro JM, Calasans-Maia MD. Early osseointegration driven by the surface chemistry and wettability of dental implants. J Appl Oral Sci 2015;23(3):279-87.

29. Chrcanovic BR, Pedrosa AR, Martins MD. Chemical and topographic analysis of treated surfaces of five different commercial dental titanium implants. Mater Res 2012;15(3):372-382.

30. d'Avila S, dos Reis LD, Piattelli A, Aguiar KCS, de Faveri M, Borges FL, lezzi G, Oliveira NTC, de G. Cardoso LA, Shibli JA. Impact of Smoking on Human Bone Apposition at Different Dental Implant Surfaces: A Histologic Study in Type IV Bone. J Oral Implantol 2010;36(2):85-90.

31. Baena RRY, Arciola CR, Selan L, Battaglia R, Imbriani M, Rizzo S, Visai L. Evaluation of Bacterial Adhesion on Machined Titanium, Osseotite ${ }^{\circledR}$ and Nanotite ${ }^{\circledR}$ Discs. Int J Artif Organs 2012;35(10):754-761.

32. Moretti L, Consolaro A, Bel A, Jr N, Souza SS De. Microtopography of titanium implants with different surface treatments from scanning electron microscopy and atomic force microscopy. Clin Oral Implants Res 2015;262015.

33. Zhao G, Schwartz Z, Wieland M, Rupp F, Geis-Gerstorfer J, Cochran DL, Boyan BD. High surface energy enhances cell response to titanium substrate microstructure. J Biomed Mater Res - Part A 2005;74(1):49-58, 